\title{
CHANGES IN SOIL MICROBIAL COMMUNITIES AS A RESULT OF GROWING BRASSICACEAE CROPS
}

\author{
Barbara Majchrzak, Tomasz P. Kurowski, Urszula Wachowska, Edyta Jaźwińska
}

\begin{abstract}
Department of Phytopathology and Entomology, University of Warmia and Mazury, Prawocheńskiego 17, 10-722 Olsztyn, Poland, e-mail: majba@uwm.edu.pl
\end{abstract}

Received: 24.09.2009

\begin{abstract}
The study was conducted in $2006-2008$ at the Production and Experimental Station of the University of Warmia and Mazury in Olsztyn, located in Bałcyny (NE Poland). The objective of this study was to determine the microbial quality of soil after Brassicaceae grown as forecrops for winter wheat. A field experiment was established on grey-brown podsolic soil, and it involved the following forecrops: winter rapeseed, spring rapeseed, white mustard, Chinese mustard, and winter wheat as control. Soil samples for microbiological analyses were collected in the spring, before the sowing of forecrops, and in the autumn, after the harvest of Brassicaceae and ploughing-in crop residues. Bacterial and fungal communities isolated from soil sown with Brassicaceae as forecrops were generally more abundant and diverse. These communities exerted an inhibitory effect on the growth of soil pathogens. Forecrops with the greatest microbiological potential were white mustard and winter rapeseed.
\end{abstract}

Key words: forecrops, wheat, Brassicaceae, soil, fungi, bacteria

\section{INTRODUCTION}

Cereal growing in monoculture contributes to a substantial yield decrease (K u r ow s ki, 2002), which may be caused by changes in the abundance and biological activity of soil microbes. The growing of a single crop leads to the selection of soil-dwelling microorganisms - some species are eliminated, while the populations of other species expand (B is et al. 2005). Changes that promote the growth of soil pathogens are particularly undesirable. The presence of crops showing phytosanitary effect in crop rotation, including species of the family Brassicaceae, may contribute to a decrease in the counts of pathogenic microorganisms and to an increase in the abundance of saprotrophs exhibiting antagonistic activity against soil pathogens (Sturz and Bernier, 1989).
Soil-born microbes include species with antagonistic properties against phytopathogens, such as fungi of the genera Trichoderma, Gliocladium and Penicillium as well as bacteria of the genera Pseudomonas and Azotobacter (P i ę t a , 1998; G a r b e v a et al. 2004). The phytosanitary quality of soil may be evaluated on the base of the population size of soil-born microbial communities. Bacteria of the genus Pseudomonas form the most abundant and best investigated group of bacteria developing in the soil environment. Pseudomonas spp. can colonize the roots of crops and successfully compete with pathogens for space and nutrients. They also secrete various substances with antagonistic properties against cereal pathogens ( $\mathrm{Paul}$ and Clark, 2000; Garbeva et al. 2004). Bacteria of the genus Azotobacter are also commonly found in the soil environment. They produce hormones stimulating plant growth and supply plants with nitrogen fixed with the enzyme nitrogenase (P a u $\mathrm{l}$ and $\mathrm{Cl} \mathrm{ark}, 2000)$.

The objective of this study was to determine the effect of selected species of the family Brassicaceae, grown as forecrops for winter wheat, on the quantitative and qualitative composition of soil-dwelling microbes.

\section{MATERIALS AND METHODS}

Field experiment. The study was conducted in 2006-2008. The experimental material comprised soil samples collected in an exact field experiment carried out at the Production and Experimental Station in Bałcyny near Ostróda, Province of Warmia and Ma-

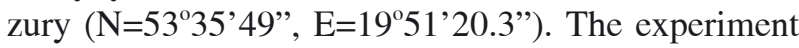
was established on typical medium-silty grey-brown podsolic soil developed from light loam, of quality class IIIa and good wheat complex. Brassicaceae plants were grown in accordance with the relevant cultivation and fertilization standards. Mineral NPK fertilizers were applied as follows $\left(\mathrm{kg}^{\prime} \mathrm{ha}^{-1}\right)$ : winter 
rapeseed - 240:70:220, spring rapeseed and white mustard - 100:40:120, Chinese mustard -70:30:80. Crop protection chemicals were applied as recommended by the Institute of Plant Protection. Before sowing, rape seeds were dressect with Crusier OSR 322 FS (thiamethoxam + matalaxyl-M + fludioxinal), and mustard seeds with TC (thiram). The plantation was protected against pests with insecticides when the economic threshold of harmfulness was exceeded.

The exact field trial was performed in a randomized block design, in three replications, and it involved the following forecrops:

- winter rapeseed (Brassica napus var. arvensis f. bienis) cv. Californium;

- spring rapeseed (Brassica napus var. arvensis f. annua) cv. Hunter;

- white mustard (Sinapis alba L.) cv. Borowska;

- Chinese mustard (Brassica juncea L.) cv. Małopolska;

- winter wheat (Triticum aestivum L.) cv. Dorota - as control.

Soil sampling. Soil samples for mycological analysis were collected into sterile Petri dishes twice: in the spring, before the sowing of forecrops, and in the autumn, after the harvest of Brassicaceae and ploughing-in crop residues. Soil was sampled at three evenly distributed points in each plot, at a depth of 5-15 cm, under aseptic conditions. A bulk sample of three replicates was placed in each dish. Bacteria were isolated from soil samples collected in the autumn of 2007 and 2008.

Mycological analysis of soil. Fungi were isolated from soil at the laboratory as described by $\mathrm{M}$ a ń $\mathrm{k}$ a (1974). $149 \mathrm{~g}$ of quartz sand was put into a 0.51 conical flask which was sterilized in an autoclave for $25 \mathrm{~min}$. $1 \mathrm{~g}$ of soil was added to cooled sand. The flask was shaken manually for $2 \mathrm{~min}$. The mixture was transferred to Petri dishes with a measuring scoop ( $25 \mathrm{mg})$, and cool Martin-Johnson agar medium was poured into the dishes. After several days of incubation at $25^{\circ} \mathrm{C}$, the colonies were inoculated onto PDA slants and were kept in a thermostat until microscopic identification based on sporulation.

Isolates of bacteria. Bacterial isolates were obtained from the soil in which winter wheat, winter rapeseed and white mustard had been grown. They are listed in Table 2. The activity of bacteria against pathogens was tested immediately after isolation.

Isolates of pathogens. The fungus Rhizoctonia cerealis was isolated from the stem bases of winter wheat showing symptoms of sharp eyespot. The species Gaeumannomyces graminis was isolated from the roots of winter wheat. The cultures were stored on PDA at $4^{\circ} \mathrm{C}$.

Isolation of soil bacteria. Bacteria of the genera Pseudomonas and Azotobacter and chitin-degrading bacteria were isolated from the soil in which winter wheat, winter rapeseed and white mustard had been grown. $10 \mathrm{~g}$ of soil was put into $250 \mathrm{ml}$ flasks filled with $90 \mathrm{ml}$ of sterile water. The samples were shaken for $30 \mathrm{~min}$. in a shaker, type $358 \mathrm{~S}$ (frequency 170/min, amplitude 8). Bacteria were isolated from soil by plating soil dilutions on selective media ( $\mathrm{H} \mathrm{i} \mathrm{d} \mathrm{-}$ din k et al. 2005; W a chow s k a et al. 2006).

Inhibitory effect of Pseudomonas bacteria. The antagonistic activity of 55 isolates of Pseudomonas bacteria against the causal agents of take-all diseases of cereals, Gaeumannomyces graminis and Rhizoctonia cerealis, was determined under laboratory conditions. 5-mm PDA disks overgrown with 10-day pathogenic cultures were placed on Petri dishes filled with PDA ( $\mathrm{Garbeva}$ et al. 2004). The isolates of the tested bacteria were placed within $2 \mathrm{~cm}$ from the pathogen (W achowska et al. 2003). Images of Petri dishes with fungal colonies were obtained with a digital camera (Nikon Coolpix 2500) and stored as data on a computer. The isolates of the genus Pseudomonas which caused changes in the shape of phytopathogen colonies were considered to be biologically active, at the coefficient of the colony's ellipticity below 0.79 .

Statistical analysis of results. Data from bacteriological analyses were verified statistically using Statistica 8.0 software. Data on bacterial counts in soil were transformed according to the formula: $\log 10(\mathrm{x}+1)$, and were subjected to an analysis of variance. The significance of differences between mean values was estimated by the Student-Newman-Keuls (SNK) test.

\section{RESULTS}

The microbiological analysis of soil revealed wide biodiversity of fungal and bacterial communities (Tables 1, 2). Aureobasidium pullulans (13.4\%), fungi of the genera Fusarium (7.9\%) and Penicillium (9.5\%), as well as various species of the family Mucoraceae $(25.8 \%)$, were isolated most frequently from soil before the experiment had been established. Fungal species potentially pathogenic to cereals and other crops accounted for $13.5 \%$ in this environment. A considerable number of antagonistic fungi, such as Mucoraceae, members of the genera Penicillium, Trichoderma and Gliocladium, were also isolated from this type of soil. They accounted for $42.8 \%$ of all analyzed colonies.

Fungal communities isolated from soil used for growing the investigated forecrops differed in both abundance and species composition (Fig. 1). The highest number of fungi characterized by the most diverse species composition were isolated from white mustard plots (664 isolates belonging to 87 species), and their lowest abundance was noted in winter rapeseed plots (556 isolates representing 70 species). The following 
fungal species occurred in greatest abundance in soil in which Brassicaceae had been grown: members of the genera Aureobasidium, Fusarium, Penicillium, Phoma and Spicaria, and representatives of the family Mucoraceae (Mortierella, Mucor, Rhizopus). They accounted for more than $50 \%$ of all isolates (Table 1).
A. pullulans dominated in this environment. Fungal species considered pathogenic to crops were most abundant in soil used for growing white mustard $(12.8 \%)$ and spring rapeseed $(12.7 \%)$. The largest group among them was formed by members of the genus Fusarium, in particular $F$. equiseti and $F$. solani.

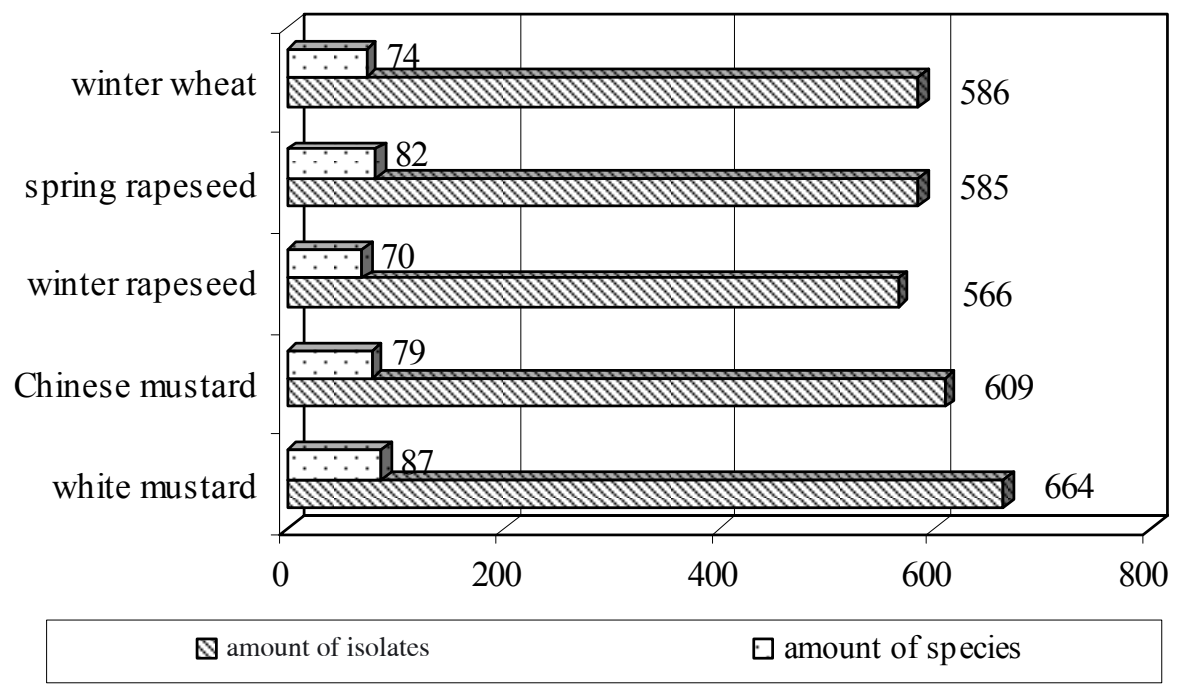

Fig. 1. Number of fungi isolated from soil after different forecrops in years 2006-2008

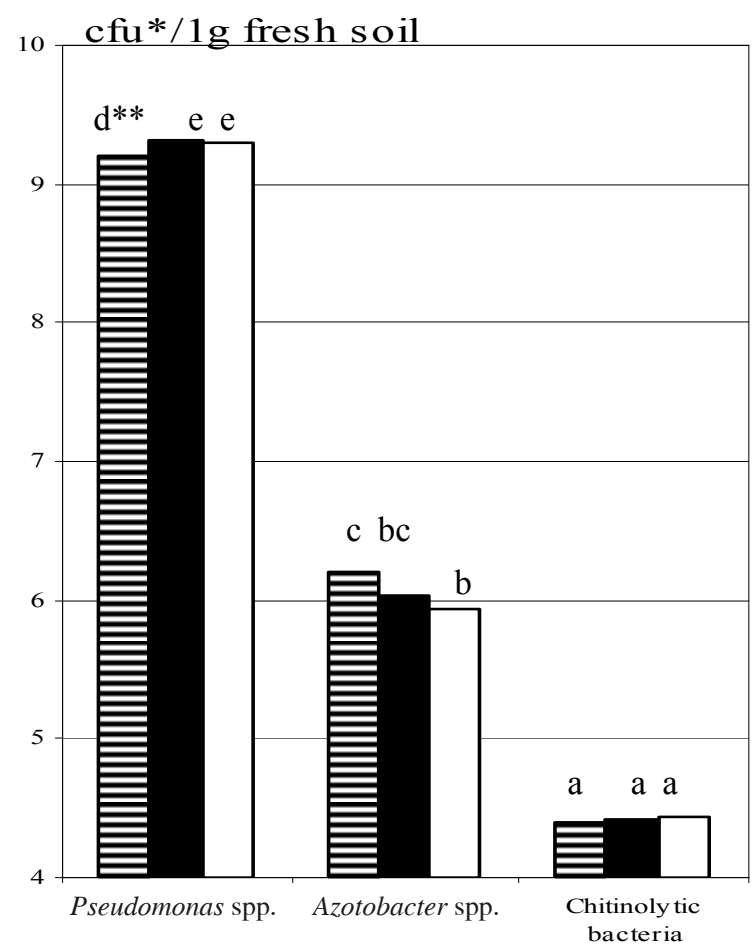

日 winter wheat

white mustard $\square$ winter rapeseed

Fig. 2. Number of bacteria isolated from soil after different forecrops

* colony forming units

** mean values followed by the same letters are not significantly different according to SNK test $(\mathrm{p}=0.01)$ 
Fungi showing antagonistic activity against crop pathogens, such as Penicillium, Trichoderma and Gliocladium, were isolated primarily from white mustard $(36.2 \%)$ and winter rapeseed $(35.2 \%)$ plots. $7.5 \%$ of pathogenic fungi and $29.0 \%$ of fungi with antagonistic properties were obtained from wheat plots.

Pseudomonas bacteria occurred in greatest abundance, compared with the remaining bacterial groups, regardless of the forecrop (Fig. 2). $94.7 \times 10^{6}$ colony-forming units (cfu) were obtained per gram of soil on average (Fig. 2). A community of diasotrophs of the genus Azotobacter developed relatively dynamically $\left(0.15 \times 10^{6} \mathrm{cfu}\right.$ per gram of soil on average). A community of chitinolytic bacteria was found to be least abundant $\left(1.41 \times 10^{3} \mathrm{cfu}\right.$ per gram of soil an average).

The communities of Pseudomonas bacteria isolated from soil used for growing white mustard and winter rapeseed were more abundant (by $29.7 \%$ and $34.4 \%$, respectively) than the communities of these bacteria obtained from winter wheat plots (Fig. 2). The differences were statistically significant. The inhibito- ry activity of isolates of Pseudomonas bacteria against the causal agents of take-all diseases of cereals, Gaeumannomyces graminis and Rhizoctonia cerealis, varied widely (Table 2). G. graminis showed a stronger response to the presence of bacteria on PDA than $R$. cerealis. The majority of isolates obtained from soil sown with winter rapeseed and white mustard as forecrops $(54.0 \%$ and $88.0 \%$, respectively) substantially inhibited the growth of $G$. graminis. $64.0 \%$ of isolates from white mustard plots also exhibited an antagonistic effect on $R$. cerealis. The isolates obtained from soil used for growing wheat were characterized by low inhibitory activity against the tested phytopathogens. Only two of them (13.0\% of the total number) considerably limited the growth of G. graminis, and one inhibited the development of $R$. cerealis.

A community of diasotrophs was significantly more abundant in winter wheat plots than in white mustard plots (Fig. 2). No statistically significant differences were noted between the communities of chitinolytic bacteria dwelling in soil in which different forecrops had been grown.

Table 1

Fungi isolated from soil after different forecrops in years 2006 -2008

\begin{tabular}{|c|c|c|c|c|c|c|c|}
\hline \multirow[b]{2}{*}{ Species of fungi } & \multirow{2}{*}{$\begin{array}{c}\text { Before } \\
\text { sowing } \\
\%\end{array}$} & \multicolumn{4}{|c|}{ Brassicaceae \% } & \multirow[b]{2}{*}{$\overline{\mathrm{x}} \%$} & \multirow{2}{*}{$\begin{array}{c}\text { Winter } \\
\text { wheat \% }\end{array}$} \\
\hline & & $\begin{array}{l}\text { White } \\
\text { mustard }\end{array}$ & $\begin{array}{l}\text { Chinese } \\
\text { mustard }\end{array}$ & $\begin{array}{l}\text { Winter } \\
\text { rapeseed }\end{array}$ & $\begin{array}{l}\text { Spring } \\
\text { rapeseed }\end{array}$ & & \\
\hline Acremonium spp. & 1.99 & 6.17 & 5.91 & 6.71 & 5.47 & 6.06 & 3.41 \\
\hline Acrostalagmus cinnabarinus Corda & 1.00 & 1.81 & 2.30 & 0.71 & 0.51 & 1.36 & 0.85 \\
\hline Alternaria alternata (Fr.) Keissler & & 5.42 & 2.96 & 1.41 & 2.39 & 3.14 & 3.07 \\
\hline Arachniotus sp. & 0.50 & & & & & & \\
\hline Arthrinium sphaerospermum Fuckel & & 1.96 & 0.49 & 1.24 & 0.68 & 1.11 & 1.88 \\
\hline Ascochyta pisi Lib. & 1.49 & & & & & & \\
\hline Ascochyta sp. & & 0.30 & & & & 0.08 & \\
\hline Aspergillus amstelodami (Mangin) Thom et Church & & 0.75 & 0.33 & 1.94 & 1.03 & 0.99 & 0.34 \\
\hline Aspergillus flavus Link & & 0.45 & & 0.71 & & 0.29 & \\
\hline Aspergillus nidulans (Eidam) Winter & & 0.45 & 0.66 & & & 0.29 & 0.34 \\
\hline Aspergillus niger van Teighem & & & & & & & 0.34 \\
\hline Aspergillus ochraceous Wilhelm & & & & 0.18 & & 0.04 & \\
\hline Aspergillus restrictus Smith & & & 0.16 & & & 0.04 & \\
\hline $\begin{array}{l}\text { Aspergillus sydowi (Bainier et Sartory) Thom et } \\
\text { Church }\end{array}$ & 0.50 & & & & & & \\
\hline Aspergillus ustus (Bainier) Thom et Chuch & & & & & 0.17 & 0.04 & \\
\hline Aspergillus sp. & 1.99 & & & & & & \\
\hline Aureobasidium bolleyi (Sprague) von Arx & 1.00 & 0.45 & 0.16 & 1.59 & 0.34 & 0.62 & \\
\hline Aureobasidium pullulans (de Bary) Arnaud & 13.43 & 6.93 & 13.30 & 16.78 & 14.36 & 12.62 & 17.58 \\
\hline Bipolaris sorokiniana (Sacc.) Shoem. & 2.49 & 0.15 & & & & 0.04 & \\
\hline
\end{tabular}


Table 1 cont.

\begin{tabular}{|c|c|c|c|c|c|c|c|}
\hline \multirow[b]{2}{*}{ Species of fungi } & \multirow{2}{*}{$\begin{array}{c}\text { Before } \\
\text { sowing } \\
\%\end{array}$} & \multicolumn{4}{|c|}{ Brassicaceae \% } & \multirow{2}{*}{$\overline{\mathrm{x}} \%$} & \multirow{2}{*}{$\begin{array}{l}\text { Winter } \\
\text { wheat \% }\end{array}$} \\
\hline & & $\begin{array}{l}\text { White } \\
\text { mustard }\end{array}$ & $\begin{array}{l}\text { Chinese } \\
\text { mustard }\end{array}$ & $\begin{array}{l}\text { Winter } \\
\text { rapeseed }\end{array}$ & $\begin{array}{l}\text { Spring } \\
\text { rapeseed }\end{array}$ & & \\
\hline Botryotrichum piluliferum Sacc. et Marchal & & 0.15 & & & & 0.04 & \\
\hline Botryodiplodia sp. & & & & & 0.34 & 0.08 & \\
\hline Botrytis cinerea Pers. ex Pers. & & 0.30 & 0.33 & 0.00 & 0.17 & 0.21 & 0.34 \\
\hline Chaetomium spp. & 2.99 & 1.66 & 2.13 & 1.41 & 2.56 & 1.94 & 4.61 \\
\hline $\begin{array}{l}\text { Chloridium virescens (Pers. ex Fr.) } \\
\text { W. Gams et Hol.-Jech. }\end{array}$ & 0.50 & & & & & & \\
\hline Cladosporium cladosporioides (Fresen.) de Vries & 1.00 & 0.90 & 3.12 & 3.36 & 3.59 & 2.68 & 3.24 \\
\hline Coniothyrium sp. & 2.49 & 1.36 & 0.82 & 3.53 & 3.59 & 2.27 & 1.37 \\
\hline Coniella sp. & & 0.15 & & & & 0.04 & \\
\hline Coremiopsis spicarioides Kamyschko & & 0.45 & 0.49 & 0.53 & 1.03 & 0.62 & 0.51 \\
\hline Cylindrocarpon spp. & & 1.05 & 0.33 & 0.53 & 0.17 & 0.54 & 0.17 \\
\hline Dendryphion sp. & & 0.30 & 1.15 & & 0.17 & 0.41 & 0.34 \\
\hline Dimargaris spp. & 8.96 & 0.15 & 0.33 & 0.88 & 0.17 & 0.37 & 0.34 \\
\hline Endothia sp. & 0.50 & 0.45 & 2.13 & & & 0.66 & 0.17 \\
\hline Fusarium aquaeductuum (Radlk. et Rabenh.) Lagerh. & & & & 0.53 & 0.85 & 0.33 & \\
\hline Fusarium chlamydosporum Wollenw. et Reinking & & 0.15 & & & & 0.04 & \\
\hline Fusarium coeruleum (Libert) ex Sacc. & 1.00 & & & & & & \\
\hline Fusarium culmorum (W.G. Smith) Sacc. & & 0.15 & 0.33 & & & 0.12 & \\
\hline Fusarium dimerum (Penzing) Raillo & & 0.30 & 0.82 & 0.53 & 1.03 & 0.66 & 0.51 \\
\hline Fusarium equiseti (Corda) Sacc. & 1.00 & 3.92 & 2.79 & 2.12 & 3.76 & 3.18 & 2.90 \\
\hline Fusarium merismoides Corda & 1.49 & 0.75 & 0.49 & 0.35 & 1.37 & 0.74 & 0.34 \\
\hline Fusarium oxysporum Schlecht. & 1.00 & 0.60 & 1.31 & 0.88 & 2.39 & 1.28 & 0.51 \\
\hline Fusarium poae (Peck) Wollen. & & 0.15 & & & & 0.04 & \\
\hline Fusarium sambucinum Fuckel & 0.50 & & & & & & \\
\hline Fusarium sacchari (Butler) W. Gams & & & & & & & 0.34 \\
\hline Fusarium solani Mart.) Appel et Wollenw. & 1.49 & 2.41 & 1.64 & 1.06 & 0.34 & 1.40 & 1.88 \\
\hline Fusarium tabacinum (Beyma) W. Gams & 1.00 & 1.05 & 0.82 & & 0.51 & 0.62 & \\
\hline Fusarium tricinctum (Corda) Sacc. & & & 0.16 & & & 0.04 & \\
\hline Fusarium verticillioides (Sacc.) Nirenberg & 0.50 & & & & & & \\
\hline Fusarium sp. & & & 0.16 & & 0.34 & 0.12 & \\
\hline Gaeumannomyces graminis (Sacc.) Arx et Olivier & & 0.75 & 0.16 & 0.18 & 0.68 & 0.45 & \\
\hline Gliocladium spp. & 2.49 & 1.36 & 3.28 & 1.59 & 3.93 & 2.52 & 1.19 \\
\hline Gliomastix spp. & 1.00 & 2.86 & 1.31 & 0.18 & 1.37 & 1.49 & 1.71 \\
\hline Gonytrichum macrocladum (Sacc.) Hughes & & & & 0.18 & 0.17 & 0.08 & \\
\hline Graphium sp. & & 0.45 & & & & 0.12 & \\
\hline Gymnoascus subumbrinus Shmith et Ramsbottom & & & 0.16 & & & 0.04 & 0.85 \\
\hline Humicola spp. & 3.48 & 2.26 & 0.16 & 2.12 & 0.68 & 1.32 & 0.17 \\
\hline
\end{tabular}


Table 1 cont.

\begin{tabular}{|c|c|c|c|c|c|c|c|}
\hline \multirow[b]{2}{*}{ Species of fungi } & \multirow{2}{*}{$\begin{array}{c}\text { Before } \\
\text { sowing } \\
\%\end{array}$} & \multicolumn{4}{|c|}{ Brassicaceae \% } & \multirow[b]{2}{*}{$\overline{\mathrm{x}} \%$} & \multirow{2}{*}{$\begin{array}{c}\text { Winter } \\
\text { wheat } \%\end{array}$} \\
\hline & & $\begin{array}{l}\text { White } \\
\text { mustard }\end{array}$ & $\begin{array}{l}\text { Chinese } \\
\text { mustard }\end{array}$ & $\begin{array}{c}\text { Winter } \\
\text { rapeseed }\end{array}$ & $\begin{array}{c}\text { Spring } \\
\text { rapeseed }\end{array}$ & & \\
\hline Kickxella alabastrina Coem. & & & & & 0.17 & 0.04 & \\
\hline Microdochium nivale (Fr.) Sammuel et Hallett & 0.50 & 0.45 & 0.16 & 1.06 & 1.03 & 0.66 & 0.51 \\
\hline Monocillium spp. & 0.50 & & 0.33 & 0.18 & 0.17 & 0.17 & \\
\hline Monodictys levis (Wiltshire) Hughes & & & 0.16 & & 0.34 & 0.12 & 0.17 \\
\hline Mortierella spp. & 11.44 & 8.13 & 5.91 & 7.60 & 8.03 & 7.43 & 3.75 \\
\hline Mucor spp. & 0.50 & 3.77 & 1.48 & 1.24 & 0.68 & 1.86 & 0.68 \\
\hline Paecilomyces niveus Stolk et Samson & & & & & 0.17 & 0.04 & \\
\hline Penicillium nigricans (Bain.)Thom & 0.50 & & & & 0.17 & 0.04 & \\
\hline Penicillium sp. & 8.96 & 12.20 & 2.46 & 9.19 & 5.30 & 7.38 & 8.53 \\
\hline Periconia spp. & & 0.45 & 0.49 & & 1.03 & 0.50 & \\
\hline Perisporium funiculatum Preuss & & & & 0.71 & & 0.17 & 0.34 \\
\hline Phoma spp. & 0.50 & 5.42 & 6.40 & 8.30 & 4.10 & 6.02 & 3.24 \\
\hline Pyrenochaeta sp. & 1.49 & 1.66 & 0.33 & 0.88 & 0.51 & 0.87 & \\
\hline Pythium rostratum Butler & & & 0.16 & & 0.68 & 0.21 & \\
\hline Reissia naumovii Kamyschko & & & & & & & 0.17 \\
\hline Rhinocladiella sp. & & & & & & & 0.17 \\
\hline Rhizoctonia solani Kühn & 1.00 & 0.30 & & 0.18 & & 0.12 & \\
\hline Rhizopus nigricans Ehrenbreg & 5.47 & 2.26 & 0.82 & 2.12 & 2.22 & 1.86 & 2.90 \\
\hline Sarcinella sp. & & 0.15 & & & 0.85 & 0.25 & \\
\hline Scytalidium lignicola Pesante & & 0.15 & & & 0.17 & 0.08 & \\
\hline Spicaria spp. & 1.49 & 5.57 & 11.49 & 1.41 & 3.93 & 5.69 & 9.39 \\
\hline Sporotrichum spp. & 0.50 & 1.36 & 3.94 & 2.12 & 4.10 & 2.85 & 3.58 \\
\hline Stysanus medius Sacc. & & 0.45 & & & & 0.12 & \\
\hline Trichocladium asperum Harz & & 0.15 & & & & 0.04 & 0.17 \\
\hline Trichoderma aureoviride Rafii & 1.49 & 1.36 & 4.27 & 1.06 & 1.03 & 1.94 & 5.12 \\
\hline Trichoderma hamatum (Bon.) Bain. & 6.47 & 3.31 & 2.30 & 4.77 & 2.91 & 3.30 & 2.39 \\
\hline Trichoderma harzianum Rafii & 1.99 & & 0.99 & 2.12 & 0.68 & 0.91 & 0.17 \\
\hline Trichoderma koningii Oud. & 0.50 & 0.45 & 1.64 & 1.59 & 0.51 & 1.03 & 0.34 \\
\hline Trichoderma polysporum (Link ex Pers.) Rifai & 0.50 & 1.20 & 2.46 & 0.35 & 2.39 & 1.61 & 1.37 \\
\hline Trichoderma viride Pers. et Gray & & 0.30 & & 0.71 & 0.51 & 0.37 & 1.37 \\
\hline Trichothecium roseum Link & & & & 0.18 & & 0.04 & \\
\hline Verticillium spp. & & 0.45 & 2.96 & 1.06 & 2.91 & 1.82 & 4.10 \\
\hline Volutella ciliata Fries & 0.50 & & & & & & \\
\hline Zygorhynchus heterogamus (Vuill.) Vuill. & & 0.15 & & & & 0.04 & 0.17 \\
\hline Non-sporulating fungi & & 1.36 & 0.49 & 1.94 & 1.20 & 1.24 & 2.05 \\
\hline Total & 100 & 100 & 100 & 100 & 100 & 100 & 100 \\
\hline
\end{tabular}


Table 2

The values of the pathogen colony's ellipticity coefficient

\begin{tabular}{|c|c|c|c|c|c|c|c|c|}
\hline \multirow{2}{*}{ Isolates } & \multicolumn{2}{|c|}{ Winter rapeseed } & \multirow{2}{*}{ Isolates } & \multicolumn{2}{|c|}{ White mustard } & \multirow{2}{*}{ Isolates } & \multicolumn{2}{|c|}{ Winter wheat } \\
\hline & R. cerealis & G. graminis & & R. cerealis & G. graminis & & R. cerealis & G. graminis \\
\hline B2 & 0.98 & 0.66 & B148 & 1.00 & 0.98 & B134 & 1.00 & 0.99 \\
\hline B3 & 1.01 & 0.93 & B23 & 1.01 & 1.03 & B136 & 1.00 & 1.02 \\
\hline B13 & 0.99 & 1.00 & $\mathrm{~J} 25$ & 0.66 & 0.71 & B137 & 1.00 & 1.10 \\
\hline B14 & 0.97 & 1.00 & J37 & 0.74 & 0.65 & B138 & 1.04 & 1.00 \\
\hline B124 & 1.00 & 0.93 & J24 & 0.73 & 0.72 & B140 & 1.01 & 0.95 \\
\hline B126 & 1.00 & 1.05 & J29 & 0.89 & 0.69 & B141 & 1.02 & 0.80 \\
\hline B127 & 0.97 & 0.68 & J64 & 0.80 & 0.79 & B143 & 1.00 & 0.98 \\
\hline B128 & 0.97 & 0.75 & $\mathrm{~J} 33$ & 0.75 & 0.62 & B144 & 1.01 & 1.00 \\
\hline B129 & 1.00 & 0.97 & J51 & 0.70 & 0.59 & B145 & 1.01 & 0.99 \\
\hline B130 & 1.00 & 0.87 & $\mathrm{~J} 28$ & 0.80 & 0.83 & B146 & 0.99 & 0.91 \\
\hline B132 & 1.00 & 0.92 & $\mathrm{~J} 34$ & 0.69 & 0.55 & B15 & 1.01 & 1.00 \\
\hline B133 & 1.02 & 0.99 & $\mathrm{~J} 18$ & 0.70 & 0.57 & $\mathrm{~J} 113$ & 0.86 & 0.61 \\
\hline J135 & 0.72 & 0.68 & $\mathrm{~J} 32$ & 0.66 & 0.64 & J92 & 0.75 & 0.90 \\
\hline J143 & 0.74 & 0.61 & J74 & 0.67 & 0.78 & J98 & 0.91 & 0.62 \\
\hline J144 & 0.91 & 0.68 & J66 & 0.92 & 0.54 & & & \\
\hline $\mathrm{J} 127$ & 1.00 & 0.66 & $\mathrm{~J} 31$ & 0.74 & 0.75 & & & \\
\hline J146 & 0.80 & 0.57 & J57 & 0.79 & 0.75 & & & \\
\hline J134 & 0.72 & 0.58 & & & & & & \\
\hline J140 & 1.00 & 0.71 & & & & & & \\
\hline J161 & 0.81 & 0.79 & & & & & & \\
\hline $\mathrm{J} 117$ & 0.82 & 0.63 & & & & & & \\
\hline $\mathrm{J} 151$ & 0.95 & 0.85 & & & & & & \\
\hline $\mathrm{J} 118$ & 1.00 & 0.90 & & & & & & \\
\hline $\mathrm{J} 150$ & 0.86 & 0.71 & & & & & & \\
\hline
\end{tabular}

B2 ... J98 - code of cultures`symbol

\section{DISCUSSION}

Fungal communities dwelling in soil sown with Brassicaceae were found to be greatly diverse in regard of both abundance and species composition. They included pathogenic fungi as well as many genera of bacteria and fungi with antagonistic properties. According to Sturz and Bernier (1989), alternate growing of rapeseed or mustard and grain crops contributes to a reduction in the population size of pathogenic fungi such as F. culmorum, Microdochium nivale, G. graminis and Cochliobolus sativus.
The highest number of fungi with the most diverse species composition were isolated from white mustard plots, while their lowest abundance was noted in winter rapeseed plots. Bialy et al. (1990) demonstrated that species of the genera Brassica and Sinapis grown as forecrops or intercrops may reduce agrophage populations due to their allelochemical activity. Glucosinolates and the products of their breakdown, isothiocyanates, contained in the tissues of these plants vary in their activity towards soil microbes ( $\mathrm{S} \mathrm{a} \mathrm{r} \mathrm{-}$ war and Kirkegaard, 1998; Majchrzak et al. 2001). Most probably, these compounds inhib- 
ited the growth of fungi of the genus Fusarium in this study. In addition, winter rapeseed and white mustard, considered to be good forecrops, were found to exert a selective effect on the communities of Pseudomonas bacteria. The abundance of these bacteria is soil was limited by, among others, the root secretions of forecrops (B is et al. 2005). Considerably more colonies of Pseudomonas bacteria were isolated from soil used for growing winter wheat, winter rapeseed and white mustard, in comparison with the rhizosphere of oat and maize (G a r beva et al. 2004). The majority of the tested isolates obtained from soil in which Brassicaceae had been grown showed inhibitory activity against the causal agents of take-all diseases of cereals. The percentage of Pseudomonas isolates from the rhizosphere of white mustard, active against the causal agent of take-all, was particularly high, reaching $88 \%$. G r a be va et al. (2004) evaluated the activity of Pseudomonas bacteria against Rhizoctonia solani and found that on average $17.4 \%$ of isolates exhibited an inhibitory effect. In the present experiment, $6 \%$ to $64 \%$ of bacterial isolates showed inhibitory activity against $R$. cerealis, depending on the forecrop. Slightly higher abundance of beneficial bacteria, protecting plants against pathogens, was observed in winter rapeseed and white mustard plots. This is probably why soil sown with Brassicaceae is characterized by high protective potential with respect to successive crops.

According to S chippers et al. (1990), crop protection against pathogens is possible due to hydrogen cyanide produced by selected Pseudomonas isolates. Bacteria living around plant roots may produce the antibiotic 2,4-diacetyl phloroglucinol which decreases the incidence of take-all $(\mathrm{Hid} \mathrm{dink}$ et al. 2005). Another mechanism of bacterial action against pathogenic fungi involves the breakdown of chitin, the main component of the cell wall of fungi. The process is catalyzed by chitinolytic enzymes which release acetylglucosamine monomers from chitin ( $\mathrm{P} \mathrm{a} \mathrm{u} \mathrm{l}$ and Clark, 2000).

It seems that Aureobasidium pullulans - the predominant species among the tested eukaryotic microorganisms - also showed antagonistic activity against soil pathogens. The fungus is commonly found in the phyllosphere of various plants across many climate zones (D o m sch and Gams, 1969). As reported by the cited authors, this species is considered to be non-pathogenic, but it may cause root necrosis in some plants. The antagonistic activity of $A$. pullulans results primarily from its antibiotic properties ( $\mathrm{R}$ a i and $\mathrm{S}$ in $\mathrm{gh}, 1980)$. As demonstrated by $\mathrm{\iota}$ a c i c o w a et al. (1997), this fungus may act as a natural biological barrier protecting crops against the infestation by pathogenic microbes.

Members of the genus Fusarium were also present in the investigated soil, in the abundance of $5.5 \%$ to $10.6 \%$. These fungi occur commonly in the natural environment. They colonize soil as well as the aboveground and underground parts of plants, causing infections collectively referred to as fusariosis (Kwaśna et al. 1991; Majchrzak et al. 2008).

\section{Acknowledgments}

This study was partially financed by research funds for the years 2007-2010 under a research project N31003132/1670 of the Ministry of Science and Higher Education in Poland.

\section{REFERENCES}

B i aly Z., Oleszek W., Le w is J., Fenw ick i G. R., 1990. Allelopathic potential of glucosinolates (mustard oil glycosides) and their degradation products against wheat. Plant and Soil, 129: 277-281.

B is H., M a rcinkowsk a K., Zają c T., 2005. Wpływ różnych przedplonów na występowanie grzybów toksynotwórczych w ryzosferze pszenicy ozimej i jarej uprawianej w Prusach koło Krakowa. / The influence of different forecrops on the occurrence of toxin-producing fungi in rhizosphere of winter wheat and spring wheat in Prusy near Cracow. Acta Agr. Silv., XLV: 19-29.

Domsch K. H., Gams W., 1969. Variability and potential of a soil fungus population to decompose pectin, xylem and carboxymethyl-cellulose. Soil Biol. Biochem. 1: 29-36.

Garbeva P., Antonie Van Veen J., Dirk Van E1s a s J., 2004. Assessment of the diversity, and antagonism towards Rhizoctonia solani AG3, of Pseudomonas species in soil from different agricultural regimes. FEMS Microbiology Ecology, 47: 51-64.

Hiddink G. A., Van Bruggaaen A. H. C., Termorshuizen A.J., Raaijmakers J.M., Semenov A.V., 2005. Effect of organic management of soils on suppressiveness to Gaeumannomyces graminis var. tritici and its antagonist, Pseudomonas fluorescens. European J. Plant Pathol. 113: 417-435.

K u rows k i T. P., 2002. Studia nad chorobami podsuszkowymi zbóż uprawianych w wieloletnich monokulturach. / Studies of root and foot rot diseases of cereals grown in long-term monoculture. Wydawnictwo UWM w Olsztynie. Rozprawy i monografie, 56: 1-86.

Kwaśna H., Chełkowski J., Zajkowski P., 1991. Grzyby (Mycota). Tom XXII. / Fungi (Mycota). Volume XXII. Polska Akademia Nauk. Warszawa- Kraków.

Łacicowa B., Pięta D., Kiecana I., 1997. Grzyby powodujące choroby podsuszkowe jęczmienia jarego (Hordeum vulgare L.) uprawianego w monokulturze z uwzględnieniem Aureobasidium pullulans (de Bary) Arnaud. / Fungi causing root and stem rot of spring barley (Hordeum vulgare L.) cultivated in monoculture with regard to Aureobasidium pullulans (de Bary) Arnaud. 
Ann. UMCS Lublin, Polonia, sect. EEE, V: 237-254.

Majchrzak B., Okorski A., Chodorowski B., 2008. Fungi isolated from the rhizosphere of spring cruciferous plants. Acta Mycol. 43 (2): 177-187.

Majchrzak B., Wachowska U., Chodorowski B., 2001. Wpływ mieszaniny glukozynolanów na wzrost kolonii grzybów w warunkach in vitro. / Influence of glucisinolate mixture on growth of fungi in vitro. Zesz. Probl. Post. Nauk Rol. 478: 249-255.

M a ń k a K., 1974. Zbiorowiska grzybów jako kryterium oceny wpływu środowiska na choroby roślin. / Fungi communities as the indicator of environmental effect on plant diseases. Zesz. Probl. Post. Nauk Rol. 160: 9-22.

Paul E .A., Clark F. E., 2000. Mikrobiologia i biochemia gleb. / Soil microbiology and biochemistry. Wydawnictwo UMCS. Lublin: 100-191.

Pi ęt a D., 1998. Rola organizmów antagonistycznych w zwalczaniu chorób roślin. / The role of antagonistic microorganisms in the control of plant diseases. Rocz. AR Poznań. Ogrod. 27: 221-227.

Rai B., Singh D. B., 1980. Antagonistic activity of some leaf surface micro-fungi against Alternaria brassicae nad Dreschlera graminea. Trans. Br. Mycol. Soc. 75: 363-369.

S a rwa r M., Kirkega ard J. A., Wong P. T. W., Desmarchelier J. M., 1998. Biofumigation potential of brassicas. Plant and Soil, 201: 103-112.

Schippers B., Bakier A. W., B akier P. A. H. M., Van Peer R., 1990. Beneficial and deleterious effects of HCN-producing pseudomonas on rhizosphere interactions. Plant and Soil, 129: 75-83.

Sturz A. V., Bernier C. C., 1989. Influence of crop rotations on winter wheat growth and yield in relation to the dynamics of pathogenic crown and root rot fungal complexes. Can. J. Plant Path. 11: 114-121.

Wachowska U., Majchrzak B., Borawska M.,
Karpińska Z., 2003. Biological control of winter wheat pathogens by bacteria. Acta Fytotechnica et Zootechnica, 7: 345-348.

Wachowska U., Okorski A., Głowacka K., 2006. Population structure of microorganisms colonizing the soil environment of winter wheat. Plant Soil Environ. 52: $39-44$.

\section{Zmiany mikrobiologiczne w środowisku glebowym pod wpływem uprawy roślin kapustnych (Brassicaceae)}

\section{Streszczenie}

Badania prowadzono w latach 2006-2008 w Zakładzie Produkcyjno-Doświadczalnym Uniwersytetu Warmińsko Mazurskiego w Bałcynach. Celem badań było określenie jakości mikrobiologicznej środowiska glebowego jako stanowiska dla pszenicy ozimej uprawianej po roślinach kapustnych. Doświadczenie polowe założono na glebie płowej uwzględniając następujące rośliny przedplonowe: rzepak ozimy, rzepak jary, gorczycę białą, gorczycę sarepską, pszenicę ozimą jako próbę kontrolną. Wiosną przed siewem roślin przedplonowych oraz jesienią po zbiorze roślin kapustnych i przyoraniu resztek pozbiorowych pobierano próby gleby i wykonywano analizy mikrobiologiczne. Zbiorowiska bakterii i grzybów pochodzące z gleby po roślinach kapustnych były na ogół liczniejsze i bardziej różnorodne. Charakteryzowały się także większym mikrobiologicznym potencjałem inhibicyjnego oddziaływania na patogeny glebowe. Najlepszymi przedplonami pod względem mikrobiologicznym okazały się gorczyca biała i rzepak ozimy. 
